\title{
Fluorescent properties and in vitro studies of new dehydroabietic acid-based diarylamines fluorescent probes
}

\author{
Hong GAO ${ }^{1}$, Jie SONG $(\bowtie)^{2}$, Shibin SHANG ${ }^{1}$, Zhanqian SONG ${ }^{1}$ \\ 1 Institute of Chemical Industry of Forest Products, Chinese Academy of Forestry; National Engineering Laboratory of Biomass Chemical \\ Utilization/Key Laboratory of Biomass Energy and Material, Jiangsu Province, Nanjing 210042, China \\ 2 Department of Chemistry and Biochemistry, University of Michigan-Flint, Flint, MI 48502, USA
}

\begin{abstract}
A series of dehydroabietic acid-based diarylamines have been synthesized in order to investigate their fluorescent properties, photostability, cell toxicity and in vitro fluorescence imaging. The geometries as well as their molecular properties were optimized at the B3LYP/6$31 \mathrm{G}^{*}$ level using Gaussian 03. The results indicate that molecular geometry, HOMO and LUMO energies, and energy gaps are important to predict absorption and fluorescent properties. Five of the compounds can be effectively taken up by human cervical carcinoma, human hepatocellular carcinoma SMMC-7721, human gastric cancer SGC-7901 and human lung adenocarcinoma A549 cells and strong blue fluorescent signals are detected in these cells. These compounds are potential candidates for fluorescent probes in biological diagnosis.
\end{abstract}

Keywords dehydroabietic acid-based diarylamine, DFT study, fluorescent probe, in vitro imaging

\section{Introduction}

The development of molecular imaging probes is crucial for imaging technologies such as magnetic resonance imaging, X-ray computed tomography, positron emission tomography and fluorescence imaging ${ }^{[1]}$. A variety of imaging nanoprobes of those modalities have been developed for biological and biomedical applications ${ }^{[2-8]}$. Among various modalities that can be used for in vitro and in vivo imaging research, fluorescence imaging is a popular modality due to its high sensitivity with a high temporal

Received January 11, 2017; accepted January 31, 2017

Correspondence: jiesong@umich.edu resolution $^{[9-11]}$.

Pine resin is a very abundant renewable source mainly composed of diterpenic resin acids with the general formula $\mathrm{C}_{19} \mathrm{H}_{29} \mathrm{COOH}$. This raw material has a wide range of industrial uses and is also a source of fine chemicals ${ }^{[12]}$. Among resin acids, those of the abietic acid type are the most abundant and are also the most versatile for chemical synthesis due to the presence of a conjugated double bond system.

Dehydroabietic acid can easily obtained by catalytic dehydrogenation of abietic type resin acids. Considerable attention has been devoted to this easily available compound as a starting material because it can be used either as the free acid or ester for the synthesis of other important natural and/or bioactive compounds, mainly through transformations that involve the benzylic or aromatic positions of the molecule. Many fluorescent derivatizing reagents have been synthesized based on the aromatic ring, which can be used as doped emitters in organic light-emitting diodes ${ }^{[13-16]}$. However, there are very limited studies regarding the use of these fluorescent probes in bioimaging applications in living cells. Previous work demonstrates that dehydroabietic acid derivatives can be useful fluorescent probes when applied in the bioimaging of living cells ${ }^{[17-19]}$.

In this study, we extended the analysis to six dehydroabietic acid-based diarylamines (Fig. 1), recently synthesized by palladium catalyzed cross-coupling reaction using procedures described previously ${ }^{[19]}$. Analytical and spectral data (IR, ${ }^{1} \mathrm{H}$ NMR, ${ }^{13} \mathrm{C}$ NMR, and MS-ESI) can be found in the experimental section below. The studies conducted analyzed their fluorescent properties, geometries, molecular orbital and in vitro biodiagnosis function. The aim of this research was to determine if their structure-property relationship could be useful in the synthesis of better dehydroabietic acid-based arylamines fluorescent probes. 


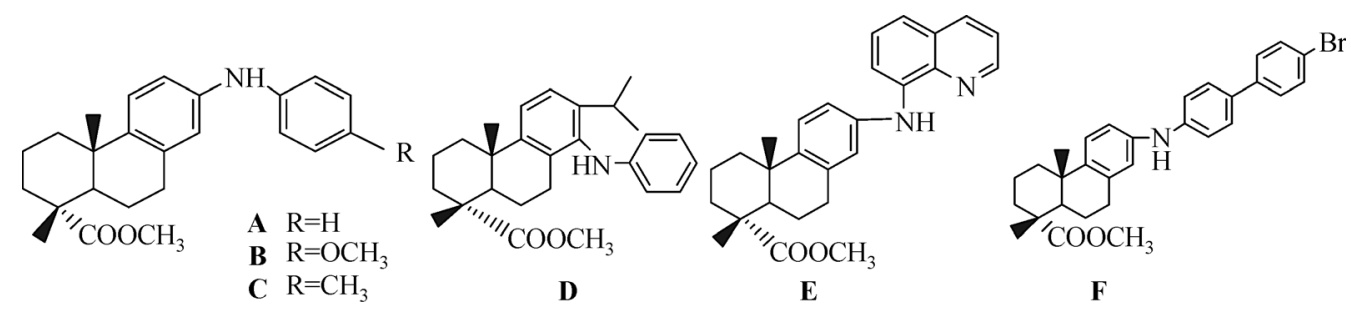

Fig. 1 Schematic diagram of the molecule structure of compounds $(\mathbf{A}-\mathbf{F})$

\section{Materials and methods}

\subsection{General procedure for the synthesis of six dehydroabietic acid-based diarylamines}

To a mixture of methyl 13-aminodeisopropyldehydroabietate or methyl 14-aminodehydroabietate $(0.1 \mathrm{mmol})$, aryl bromide $(0.11 \mathrm{mmol})$ and sodium tert-butoxide $(0.12 \mathrm{mmol})$ in dry o-xylene $(3 \mathrm{~mL})$ in a flask under nitrogen atmosphere were added tri-tert-butylphosphine $(0.01 \mathrm{mmol})$ and palladium acetate $(0.005 \mathrm{mmol})$. The mixture was stirred at $135^{\circ} \mathrm{C}$ until the complete consumption of methyl 13-aminodehydrodeisopropylabietate (2$3 \mathrm{~h}$ ) as judged by thin layer chromatography. The reaction mixture was then cooled to room temperature, taken up in diethyl ether $(5 \mathrm{~mL})$ and washed with brine. The organic phase was dried over anhydrous magnesium sulfate and filtered and concentrated under reduced pressure. The residue obtained was purified by silica column chromatography using mixtures of petroleum ether-diethyl ether (10:1) as eluent.

\subsection{Spectral data of six dehydroabietic acid-based diarylamines $(\mathbf{A}-\mathbf{F})$}

\subsubsection{Methyl 13-(phenyl)}

aminodeisopropyldehydroabietate (A)

Light yellow solid, yield: $77.3 \%, \mathrm{mp} .=72.9^{\circ} \mathrm{C}$; Anal. Calcd. for $\mathrm{C}_{24} \mathrm{H}_{29} \mathrm{NO}_{2} \mathrm{C} 79.30 \%, \mathrm{H} 8.04 \%, \mathrm{~N} 3.85 \%$. Found: C 79.50\%, H 7.98\%, N 3.70\%. IR (Smart iTR) $v_{\max } / \mathrm{cm}^{-1}:$ 3390, 2940, 1722, 1595, 1495, 1319, 1252; ${ }^{1} \mathrm{H}$ NMR(DMSO-d6, 500MHz) $\delta: 1.13\left(3 \mathrm{H}, \mathrm{s}, \mathrm{CH}_{3}\right), 1.20$ $\left(3 \mathrm{H}, \mathrm{s}, \mathrm{CH}_{3}\right), 1.26-1.33(2 \mathrm{H}, \mathrm{m}, 2 \mathrm{H}, 2 \times \mathrm{CH}), 1.56-1.77$ (5H, m, $2 \times \mathrm{CH}_{2}$ and $\left.\mathrm{CH}\right), 1.98-2.05(1 \mathrm{H}, \mathrm{dd}, \mathrm{CH}), 2.26-$ $2.29(\mathrm{~m}, 1 \mathrm{H}, \mathrm{CH}), 2.71-2.77\left(2 \mathrm{H}, \mathrm{m}, \mathrm{CH}_{2}\right), 3.61(3 \mathrm{H}, \mathrm{s}$, $\left.\mathrm{CH}_{3}\right), 6.71-6.76(2 \mathrm{H}, \mathrm{m}, 2 \times \mathrm{CH}), 6.83-6.85(1 \mathrm{H}, \mathrm{dd}, \mathrm{CH})$, 6.99-7.01 (2H, m, 2×CH), 7.10-7.12 (1H, d, CH), 7.16$7.19(2 \mathrm{H}, \mathrm{m}, 2 \times \mathrm{CH}), 7.88(1 \mathrm{H}, \mathrm{s}, \mathrm{NH}) ;{ }^{13} \mathrm{C}$ NMR (DMSOd6, $125 \mathrm{MHz}) \delta: 16.20,18.00,21.08,24.76,29.47,36.19$ (2C), 37.71, 45.01, 46.88, 51.75, 115.49, 116.04 (2C), $116.79,118.89,124.73,128.97$ (2C), 134.95, 140.46, 141.19, 143.93, 177.99; $\mathrm{m} / z(\mathrm{ESI}) 364.1[\mathrm{M}+\mathrm{H}]^{+}$.
2.2.2 Methyl 13-(4-methoxyphenyl) aminodeisopropyldehydroabietate (B)

Yellow solid, yield: $82.1 \%, \mathrm{mp} .=99.0^{\circ} \mathrm{C}$; Anal. Calcd. for $\mathrm{C}_{25} \mathrm{H}_{31} \mathrm{NO}_{3} \mathrm{C} 76.30 \%, \mathrm{H} 7.94 \%$, N 3.56\%. Found: C $76.50 \%, \mathrm{H} 7.68 \%, \mathrm{~N} 3.67 \%$. IR (Smart iTR) $v_{\max } /$ $\mathrm{cm}^{-1}$ : 3395, 2936, 1723, 1508, 1506, 1239; ${ }^{1} \mathrm{H}$ NMR (DMSO-d6, 500MHz) $\delta: 1.11\left(3 \mathrm{H}, \mathrm{s}, \mathrm{CH}_{3}\right), 1.16-1.19$ $\left(3 \mathrm{H}, \mathrm{s}, \mathrm{CH}_{3}\right), 1.24-1.39(3 \mathrm{H}, \mathrm{m}, \mathrm{CH}), 1.56-1.76(5 \mathrm{H}, \mathrm{m}$, $\mathrm{CH}_{2}$ and $\left.\mathrm{CH}\right), 1.98-2.03(1 \mathrm{H}, \mathrm{m}, \mathrm{CH}), 2.24-2.26(1 \mathrm{H}, \mathrm{dd}$, $\mathrm{CH}), 2.67-2.74\left(2 \mathrm{H}, \mathrm{m}, \mathrm{CH}_{2}\right), 3.60\left(3 \mathrm{H}, \mathrm{s}, \mathrm{OCH}_{3}\right), 3.69$ $\left(3 \mathrm{H}, \mathrm{s}, \mathrm{CO}_{2} \mathrm{CH}_{3}\right), 6.57(1 \mathrm{H}, \mathrm{s}, \mathrm{CH}), 6.69-6.71(1 \mathrm{H}, \mathrm{d}, \mathrm{CH})$, 6.81-6.83 (2H, d, CH), 6.97-6.98 (2H, d, CH), 7.03-7.05 $(1 \mathrm{H}, \mathrm{d}, \mathrm{CH}), 7.56(1 \mathrm{H}, \mathrm{s}, \mathrm{NH}) ;{ }^{13} \mathrm{C}$ NMR (DMSO-d6, $125 \mathrm{MHz}) \delta: 16.21,18.02,21.14,24.81,29.53,36.10$, $36.21,37.78,45.11,46.89,51.77,55.17,113.71,114.44$ (2C), 114.64, 119.63 (2C), 124.69, 134.84, 136.74, 139.87, 142.24, 153.33, 178.04; $\mathrm{m} / z$ (ESI) 394.1[M $+\mathrm{H}]^{+}$.

\subsubsection{Methyl 13-(4-methylphenyl)}

aminodeisopropyldehydroabietate $(\mathbf{C})$

Colorless crystal, yield: $79.0 \%, \mathrm{mp} .=77.5^{\circ} \mathrm{C}$; Anal. calcd. for $\mathrm{C}_{25} \mathrm{H}_{31} \mathrm{NO}_{2} \mathrm{C} 79.54 \%, \mathrm{H} 8.28 \%, \mathrm{~N} \mathrm{3.71 \%}$. Found: $\mathrm{C}$ 79.39\%, H 7.79\%, N 3.31\%. IR (Smart iTR) $v_{\max } / \mathrm{cm}^{-1}$ : 3386, 2932, 1719, 1607, 1512, 1247; ' H NMR (DMSOd6, $500 \mathrm{MHz}) \delta: 1.12\left(3 \mathrm{H}, \mathrm{s}, \mathrm{CH}_{3}\right), 1.20\left(3 \mathrm{H}, \mathrm{s}, \mathrm{CH}_{3}\right)$, 1.25-1.32 (2H, m, CH), 1.56-1.76 (5H, m, $\mathrm{CH}_{2}$ and $\left.\mathrm{CH}\right)$, 2.01-2.04 (1H, dd, $\mathrm{J}=1.8$ and 12.35, CH), $2.20(3 \mathrm{H}, \mathrm{s}, \mathrm{Ar}-$ $\left.\mathrm{CH}_{3}\right), 2.25-2.27(1 \mathrm{H}, \mathrm{d}, \mathrm{J}=12.9, \mathrm{CH}), 2.69-2.76(2 \mathrm{H}, \mathrm{m}$, $\left.\mathrm{CH}_{2}\right), 3.60\left(3 \mathrm{H}, \mathrm{s}, \mathrm{CO}_{2} \mathrm{CH}_{3}\right), 6.66(1 \mathrm{H}, \mathrm{s}, \mathrm{Ar}-\mathrm{H}), 6.78-$ $6.80(1 \mathrm{H}, \mathrm{dd}, \mathrm{J}=2.15$ and 8.55, Ar-H), 6.91-6.93 (2H, d, J $=8.35$, Ar-H), 6.99-7.00 (2H, d, J = 8.25, Ar-H), 7.06$7.08(1 \mathrm{H}, \mathrm{d}, \mathrm{J}=8.6, \mathrm{Ar}-\mathrm{H}), 7.73(1 \mathrm{H}, \mathrm{s}, \mathrm{NH}) ;{ }^{13} \mathrm{C} \mathrm{NMR}$ (DMSO-d6, 125MHz) $\delta: 16.19,18.01,20.16,21.11$, $24.77,29.50,36.14,36.19,37.74,45.05,46.88,51.74$, $114.73,115.88,116.89$ (2C), 124.66, 127.92, 129.39 (2C), $134.86,140.55,141.16,141.21,178.00 ; \mathrm{m} / z$ (ESI) 378.2 $[\mathrm{M}+\mathrm{H}]^{+}$.

\subsubsection{Methyl 14-(phenyl) aminodehydroabietate (D)}

Colorless crystal, yield: $46.1 \%, \mathrm{mp} .=73.7^{\circ} \mathrm{C}$; Anal. calcd. for $\mathrm{C}_{27} \mathrm{H}_{35} \mathrm{NO}_{2} \mathrm{C} 79.96 \%, \mathrm{H} 8.70 \%, \mathrm{~N} 3.45 \%$. Found: 
C $79.59 \%, \mathrm{H} 8.79 \%$, N 3.53\%. IR (KBr) $v_{\max } / \mathrm{cm}^{-1}: 3409$, 2945, 1719, 1597, 1494, 1253; ' $\mathrm{H}$ NMR (DMSO-d6, $500 \mathrm{MHz}) \delta: 1.03-1.05\left(3 \mathrm{H}, \mathrm{s}, \mathrm{CH}_{3}\right), 1.07-1.08(3 \mathrm{H}, \mathrm{d}$, $\left.\mathrm{CH}_{3}\right), 1.15\left(3 \mathrm{H}, \mathrm{s}, \mathrm{CH}_{3}\right), 1.18\left(3 \mathrm{H}, \mathrm{s}, \mathrm{CH}_{3}\right), 1.21-1.26(\mathrm{H}$, $\mathrm{m}, \mathrm{CH}), 1.32-1.37(\mathrm{H}, \mathrm{m}, \mathrm{CH}), 1.55-1.76\left(5 \mathrm{H}, \mathrm{m}, \mathrm{CH}_{2}\right.$ and $\mathrm{CH}), 1.95-1.98(1 \mathrm{H}, \mathrm{dd}, \mathrm{CH}), 2.32-2.34(\mathrm{H}, \mathrm{d}, \mathrm{CH})$, 2.49-2.55 (H, m, $\left.\mathrm{CH}_{2}\right), 2.71-2.76(1 \mathrm{H}, \mathrm{dd}, \mathrm{CH}), 3.07-$ $3.13(1 \mathrm{H}, \mathrm{m}, \mathrm{CH}), 3.56\left(3 \mathrm{H}, \mathrm{s}, \mathrm{CO}_{2} \mathrm{CH}_{3}\right), 6.30-6.34(2 \mathrm{H}$, $\mathrm{d}, \mathrm{CH}), 6.50-6.53(\mathrm{H}, \mathrm{t}, \mathrm{NH}), 7.01-7.04(3 \mathrm{H}, \mathrm{t}, \mathrm{CH}), 7.15-$ $7.16(1 \mathrm{H}, \mathrm{d}, \mathrm{CH}), 7.20-7-7.22(1 \mathrm{H}, \mathrm{d}, \mathrm{CH}) ;{ }^{13} \mathrm{C}$ NMR (DMSO-d6, 125MHz) $\delta: 16.19,18.03,20.77,23.30$, $23.73,24.85,25.73,27.07,36.10,36.63,37.77,44.45$, $46.85,51.75,111.71,115.93$ (2C), 122.41, 123.17, 128.90 (2C), 133.23, 135.94, 143.91, 147.83, 147.91, 177.97; m/z (ESI) $406.2[\mathrm{M}+\mathrm{H}]^{+}$.

\subsubsection{Methyl 13-(8-quinoline)}

aminodeisopropyldehydroabietate (E)

Yellow solid, yield: $66.8 \%$, Anal. Calcd. for $\mathrm{C}_{27} \mathrm{H}_{30} \mathrm{~N}_{2} \mathrm{O}_{2} \mathrm{C}$ $78.23 \%$, H 7.29\%, N 6.76\%. Found: C 78.62\%, H 7.68\%, $\mathrm{N} 6.81 \%$. IR (KBr) $\cup_{\max } / \mathrm{cm}^{-1}: 3368,2986,1723,1579$, 1523, 1379, 1248; ${ }^{1} \mathrm{H}$ NMR (DMSO-d6, 500MHz) $\delta: 1.17$ $\left(3 \mathrm{H}, \mathrm{s}, \mathrm{CH}_{3}\right), 1.22\left(3 \mathrm{H}, \mathrm{s}, \mathrm{CH}_{3}\right), 1.31-1.34(2 \mathrm{H}, \mathrm{m}, 2 \times \mathrm{CH})$, 1.58-1.79 $\left(5 \mathrm{H}, \mathrm{m}, 2 \times \mathrm{CH}_{2}\right.$ and $\left.\mathrm{CH}\right), 2.05-2.08(1 \mathrm{H}, \mathrm{dd}$, $J=12.45$ and $2.05, \mathrm{CH}), 2.31-2.33(1 \mathrm{H}, \mathrm{d}, J=13.0, \mathrm{CH})$, 2.78-2.84 $\left(2 \mathrm{H}, \mathrm{m}, \mathrm{CH}_{2}\right), 3.62\left(3 \mathrm{H}, \mathrm{s}, \mathrm{COOCH}_{3}\right), 7.05(1 \mathrm{H}$, s, Ar-H), 7.16-7.18 (1H, dd, $J=8.45$ and $2.30 \mathrm{Ar}-\mathrm{H}), 7.22$ $7.23(1 \mathrm{H}, \mathrm{d}, J=8.55, \mathrm{Ar}-\mathrm{H}), 7.26-7.28(1 \mathrm{H}, \mathrm{dd}, J=6.85$ and 2.50, quinoline-H), 7.39-7-7.40 $(1 \mathrm{H}, \mathrm{d}, J=1.7$, quinoline-H), 7.41-7.42 (1H, d, $J=7.7$, quinoline-H), 7.55-7-7.58 (1H, m, quinoline- $\mathrm{H}), 8.28-8.30(1 \mathrm{H}$, dd, $J=8.30$ and 1.65 , quinoline-H), $8.42(1 \mathrm{H}, \mathrm{s}, \mathrm{NH}), 8.83-$ $8.84\left(1 \mathrm{H}, \mathrm{dd}, J=4.15\right.$ and 1.65 , quinoline-H); ${ }^{13} \mathrm{C}$ NMR (DMSO-d6, 125MHz) $\delta: 16.18,17.99,21.04,24.68$, 29.43, 36.17, 36.32, 37.64, 44.88, 46.87, 51.73, 107.42, $116.05,117.78,119.46,121.84,124.85,127.25,128.53$, 135.22, 136.14, 137.90, 138.85, 140.11, 142.97, 147.43, $177.95(\mathrm{C}=\mathrm{O}) ; \mathrm{m} / z(\mathrm{ESI}) 415.3[\mathrm{M}+\mathrm{H}]^{+}$.

\subsubsection{Methyl 13-(p-bromodiphenyl)}

aminodeisopropyldehydroabietate (F)

Light yellow solid, yield: $55.0 \%, \mathrm{mp}=129.2^{\circ} \mathrm{C}$; Anal. calcd. for $\mathrm{C}_{30} \mathrm{H}_{32} \mathrm{BrNO}_{2} \mathrm{C} 69.50 \%, \mathrm{H} 6.22 \%, \mathrm{~N} 2.70 \%$. Found: C $68.90 \%$, H $6.56 \%$, N 2.30\%. IR (Smart iTR) $\cup_{\max } / \mathrm{cm}^{-1}: 3404,2933,1725,1606,1505,1249 ;{ }^{1} \mathrm{H}$ NMR (DMSO-d6, 500MHz) $\delta: 1.14\left(3 \mathrm{H}, \mathrm{s}, \mathrm{CH}_{3}\right), 1.17(3 \mathrm{H}, \mathrm{s}$, $\left.\mathrm{CH}_{3}\right), 1.18-1.37(2 \mathrm{H}, \mathrm{m}, 2 \times \mathrm{CH}), 1.40-1.79(5 \mathrm{H}, \mathrm{m}$, $2 \times \mathrm{CH}_{2}$ and $\left.\mathrm{CH}\right), 2.03-2.05(1 \mathrm{H}, \mathrm{d}, J=10.9, \mathrm{CH}), 2.28-$ $2.31(1 \mathrm{H}, \mathrm{d}, J=13.15, \mathrm{CH}), 2.73-2.79\left(2 \mathrm{H}, \mathrm{m}, \mathrm{CH}_{2}\right), 3.61$ $\left(3 \mathrm{H}, \mathrm{s}, \mathrm{COOCH}_{3}\right), 6.77(1 \mathrm{H}, \mathrm{s}, \mathrm{Ar}-\mathrm{H}), 6.89-6.90(1 \mathrm{H}, \mathrm{dd}$, $J=2.0$ and 8.5, Ar-H), 7.07-7.08 (2H, d, $J=8.6, \mathrm{Ar}-\mathrm{H})$, 7.14-7-7.16 (1H, d, $J=8.6, \operatorname{Ar}-\mathrm{H}), 7.50-7.52(2 \mathrm{H}, \mathrm{d}$, $J=8.55$, Ar-H), 7.54-7.55 (2H, d, $J=8.8$, Ar-H), 7.56- $7.58\left(2 \mathrm{H}, \mathrm{d}, J=8.65\right.$, Ar-H), $8.1(1 \mathrm{H}, \mathrm{s}, \mathrm{NH}) ;{ }^{13} \mathrm{C} \mathrm{NMR}$ (DMSO-d6, 125MHz) $\delta: 16.23,18.02,21.08,24.78$, $29.47,36.20,36.27,37.72,45.01,46.90,51.80,115.95$ (2C), 116.07, 117.45, 119.31, 124.86, 127.20 (2C), 127.63 (2C), 128.91, 131.57 (2C), 135.11, 139.28, 139.90, 141.76, 144.02, $178.03(\mathrm{C}=\mathrm{O}) ; \mathrm{m} / z(\mathrm{ESI}) 520.2[\mathrm{M}+\mathrm{H}]^{+}$.

\subsection{Procedures for in vitro assessment of cytotoxicity in} tumor cells

Human cervical carcinoma cells (HeLa), human hepatocellular carcinoma SMMC-7721 cells (SMMC-7721), human gastric cancer SGC-7901 cells (SGC-7901) and human lung adenocarcinoma A549 cells (A549), grown in DMEM with 10\% FBS (Gibco, Thermo Fisher Scientific Inc., Waltham, MA, USA), were maintained in an incubator $\left(5 \% \mathrm{CO}_{2}, 37^{\circ} \mathrm{C}\right)$. These cells were plated in 96-well plate at the density of $5 \times 10^{5}$ cells per well. $24 \mathrm{~h}$ later, serum free medium with the compound $\left(1 \mu \mathrm{mol} \cdot \mathrm{L}^{-1}\right)$ was replaced on the plates. After $24 \mathrm{~h}$ incubation in an incubator, cell viability was measured using MTT (3-[4,5dimethylthiazol-2-yl]-2,5-diphenyl tetrazolium-bromide) (Amesco) assay.

\subsection{Procedures of fluorescence imaging}

HeLa, SMMC-7721, SGC-7901 and A549 cells grown in DMEM with $10 \%$ FBS (Gibco), were maintained in an incubator $\left(5 \% \mathrm{CO}_{2}, 37^{\circ} \mathrm{C}\right)$. These cells were plated in $96-$ well plates at a density of $5 \times 10^{5}$ cells per well. Twenty four $\mathrm{h}$ later, serum free medium with the compound $\left(1 \mu \mathrm{mol} \cdot \mathrm{L}^{-1}\right)$ was replaced on the plates, separately. After $4 \mathrm{~h}$ incubation in the dark at $37^{\circ} \mathrm{C}$, the cells were washed with PBS ( $\mathrm{pH}$ 7.4) three times and monitored by fluorescence microscopy (Nikon Ti, Nikon Instruments Inc., Melville, NY, USA).

\subsection{Procedure of Density Functional Theory (DFT) study}

All theoretical calculations were performed at the B3LYP/ $6-31 \mathrm{G}^{*}$ level using Gaussian $03^{[20]}$; GaussView $04^{[21]}$ was used for the molecular visualization. Equilibrium structures were confirmed by the harmonic vibrational frequencies. Solvent effect was calculated by using three solvents with different polarities: water, methanol, and dichloromethane.

\section{Results and discussion}

\subsection{Fluorescent properties}

Absorption and fluorescent spectra were measured in a $1.0 \mu \mathrm{mol} \cdot \mathrm{L}^{-1}$ solution in methanol using a Shimadzu UV2450 spectrophotometer (Shimadzu Corp, Kyoto, Japan) and Perkin-ElmerLS-50B fluorometer (Perkin-Elmer, 
Whaltham, MA, USA), respectively. The absolute fluorescence quantum yield and decay lifetime were carried out in a $10.0 \mu \mathrm{mol} \cdot \mathrm{L}^{-1}$ solution in methanol using the Jobin-Yvon IBH-FluoroMax-4 apparatus (Horiba JobinYvon Inc., Edison, NJ, USA).

UV-Vis absorption and fluorescent spectra of compounds $\mathbf{A}-\mathbf{F}$ in methanol are shown in Fig. 2 and Fig. 3, and corresponding data are summarized in Table 1. As shown in the UV-Vis spectra, compounds A, $\mathbf{B}$ and $\mathbf{C}$ have very similar absorption spectra and show two maximum absorption peaks at 197 and $286 \mathrm{~nm}$. Compounds D, E and F have a very similar absorption peak around $197 \mathrm{~nm}$, but a very different peak at a longer wavelength. Compound D shows a blue shift to $244 \mathrm{~nm}$. Compound F, with a biphenyl moiety, shows a broad $\pi-\pi *$ transition band with a maximum absorption red shift to $322 \mathrm{~nm}^{[16,22]}$. In contrast, compound $\mathbf{E}$, which has a quinoline moiety, shows a broad $\pi-\pi^{*}$ transition bands with maximum at $263 \mathrm{~nm}$. $\epsilon$ (named molar extinction coefficient) is a measurement of how strongly a chemical species attenuates light at a given wavelength, where $\epsilon$ is larger, this indicates that the optical absorption of the solution is stronger.

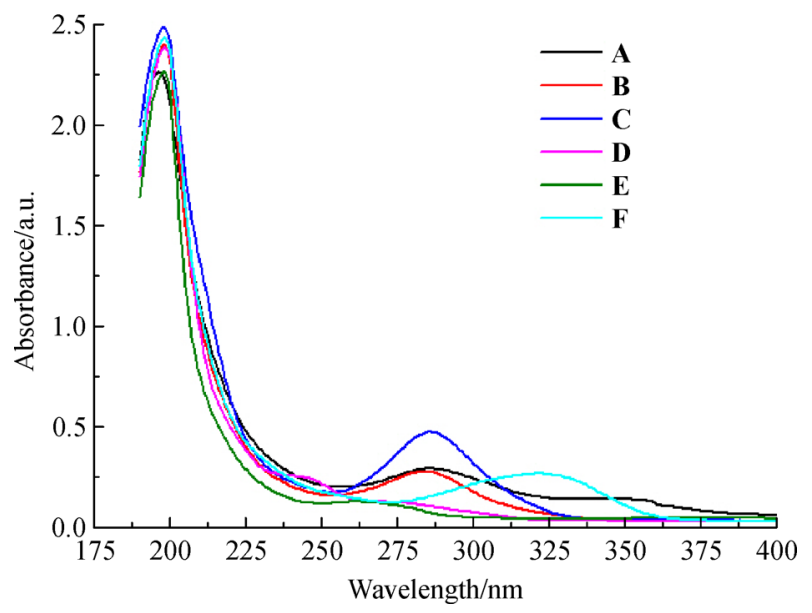

Fig. 2 UV-Vis absorption spectra of compounds $(\mathbf{A}-\mathbf{F})$ in methanol

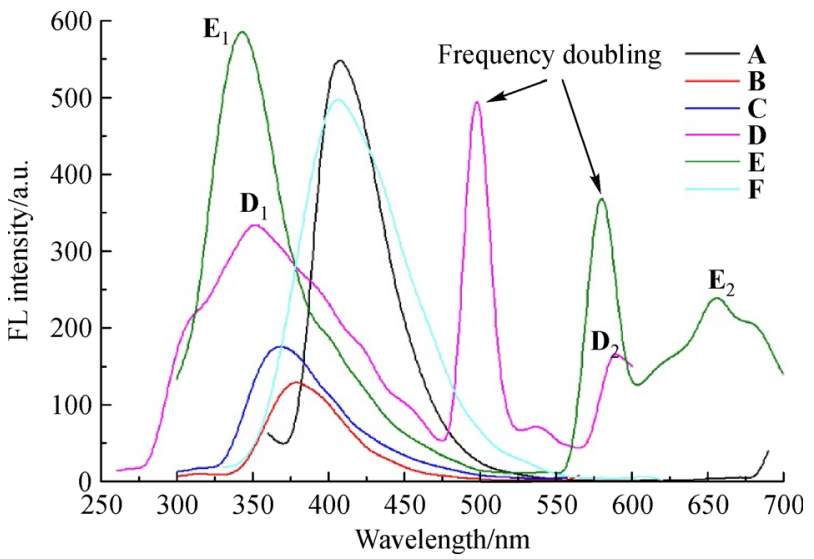

Fig. 3 Fluorescent emission spectra of compounds (A-F) in methanol

As shown in Fig. 3 and Table 1, maximum fluorescent emission wavelengths $\left(\lambda_{\text {em,max }}\right)$ of compounds $\mathbf{A}-\mathbf{F}$ in methanol range from 342 to $408 \mathrm{~nm}$, corresponding to blue light emission. The fluorescence intensity sequence of compounds $\mathbf{A}-\mathbf{F}$ is $\mathbf{E}>\mathbf{A}>\mathbf{F}>\mathbf{D}>\mathbf{C}>\mathbf{B}$. Figure 3 also shows that compounds $\mathbf{D}$ and $\mathbf{E}$ have a 2 nd emission peak, $\mathbf{D}_{2}$ and $\mathbf{E}_{2}$, in the yellow light $(590 \mathrm{~nm})$ and red light $(656 \mathrm{~nm})$ regions, respectively. This observation implies that both compounds can be candidates for dual fluorescent probes. Unlike compounds $\mathbf{B}$ and $\mathbf{C}$, compound $\mathbf{D}$ with an isopropyl unit shows a blue shift. And the introduction of a biphenyl moiety in compound $\mathbf{F}$ leads to a significant redshift of fluorescent emission spectra, due to the increase of the conjugated length. Therefore, substituents of an electron-donating and extended conjugation system have some influences on the fluorescent properties of molecules. It is noteworthy that compound $\mathbf{A}$ demonstrates a red shift to $408 \mathrm{~nm}$, while an electron-donating substituent or extended conjugation system is absent. Such a change deserves further investigations.

In addition, the fluorescence quantum yields vary from $6.10 \%$ (compound D) to $86.55 \%$ (compound A). The fluorescence lifetime $\left(\mathrm{T}_{2}\right)$ is found in the range $2.43 \mathrm{~ns}$ (compound A) to $10.92 \mathrm{~ns}$ (compound B). The

Table 1 The absorption and fluorescent spectral properties of compounds $(\mathbf{A}-\mathbf{F})$ in methanol

\begin{tabular}{|c|c|c|c|c|c|c|c|}
\hline \multirow{2}{*}{ Compound } & \multirow{2}{*}{$\lambda_{\text {abs,max }} / \mathrm{nm}^{*}$} & \multirow{2}{*}{$\begin{array}{c}\epsilon\left(\times 10^{-4}\right) \\
/\left(\mathrm{mol} \cdot \mathrm{L}^{-1} \cdot \mathrm{cm}^{-1}\right)^{* *}\end{array}$} & \multirow{2}{*}{$\lambda_{\mathrm{ex}, \max } / \mathrm{nm}^{*}$} & \multirow{2}{*}{$\lambda_{\mathrm{em}, \max } / \mathrm{nm}^{*}$} & \multirow{2}{*}{ Quantum yield $\left(\Phi_{\mathrm{f}}\right) / \%^{* * *}$} & \multicolumn{2}{|c|}{ Lifetime $\left(\tau_{\mathrm{F}}\right) / \mathrm{ns}^{* * *}$} \\
\hline & & & & & & $\mathrm{T}_{1}$ & $\mathrm{~T}_{2}$ \\
\hline $\mathbf{A}$ & 286 & 0.96 & 350 & 408 & 86.55 & 1.19 & 2.43 \\
\hline B & 285 & 1.18 & 287 & 378 & 10.63 & 2.33 & 10.92 \\
\hline $\mathbf{C}$ & 286 & 1.27 & 289 & 368 & 61.05 & 2.59 & 6.84 \\
\hline D & 244 & 1.02 & 250 & $352 / 590$ & 6.10 & 0.09 & 5.70 \\
\hline $\mathbf{E}$ & 263 & 1.70 & 290 & $342 / 656$ & 28.19 & 2.47 & 4.83 \\
\hline $\mathbf{F}$ & 322 & 0.88 & 317 & 406 & 9.89 & 0.43 & 3.32 \\
\hline
\end{tabular}

Note: ${ }^{*}$, Absorption $\left(5.0 \times 10^{-5} \mathrm{~mol} \cdot \mathrm{L}^{-1}\right)$ and fluorescent $\left(1.0 \times 10^{-6} \mathrm{~mol} \cdot \mathrm{L}^{-1}\right)$ spectra at room temperature in methanol solution; ${ }^{* *}$, referenced to the molar extinction coefficient of the peak with the strongest absorption; ${ }^{* * *}$, values determined in methanol solution $\left(1.0 \times 10^{-5} \mathrm{~mol} \cdot \mathrm{L}^{-1}\right)$. 
fluorescence quantum yields and lifetimes seem to be independent of the substituent and conjugated system.

\subsection{DFT study}

It is known that molecular structure is important in determining the absorption and fluorescent properties of aromatic molecules. Characters of the highest occupied molecular orbitals (HOMO) to lowest unoccupied molecular orbitals (LUMO) would give an understanding of the excitation readiness and distinct optical properties of the synthesized compounds ${ }^{[23]}$. In this study, structures of compounds A-F were optimized at the B3LYP/6-31G* level using Gaussian $03^{[20]}$. Sample maps of optimized geometry for compounds $\mathbf{A}$ and $\mathbf{D}$, and some selected geometric parameters of $\mathbf{A}-\mathbf{F}$, are shown in Fig. 4 and Table 2, respectively. The rest are given in supplementary materials (Fig. S1 and Table S1).

Compounds A-F contain four or five crystallographically unique rings: two cyclohexane rings, a benzene ring, and an aromatic ring (A, B, C and $\mathbf{D})$ or quinoline $(\mathbf{E})$ or biphenyl (F) ring. $\mathrm{C}-\mathrm{N}$ bond lengths, $\mathrm{C}-\mathrm{N}-\mathrm{C}$ ( or $\mathrm{C}-\mathrm{N}-\mathrm{H}$,
$\mathrm{C}-\mathrm{C}-\mathrm{N}$ ) bond angles and torsion angles at the same position of compounds $\mathbf{A}, \mathbf{B}, \mathbf{C}, \mathbf{E}$ and $\mathbf{F}$ are similar, where two phenyl rings are nearly in the same dimensional plane and enhance the delocalization of electrons between two phenyl groups. The exception is compound $\mathbf{D}$, where two phenyl rings are almost perpendicular to each other. This may be due to the steric hindrance effect from the isopropyl group on the adjacent position, therefore showing a longer $\mathrm{C}-\mathrm{N}$ bond.

Calculated results in the gas phase do not show significant difference from the ones calculated with different solvents, as shown in Table 3 , which implies that the polarity of the solvent would not affect the structure. Experimental results were obtained in the solid state, while theoretical calculations were performed on the isolated molecule in the gas phase and/or solvation effect was included. This may cause slight differences between theoretical and experimental data listed in Table $3^{[24]}$.

Sample maps of HOMO and LUMO for compound $\mathbf{A}$ are shown in Fig. 5, while other compounds can be seen in supplementary material (Fig. S2). It shows that HOMOs have $\pi$-electrons delocalized over the two benzene/aryl

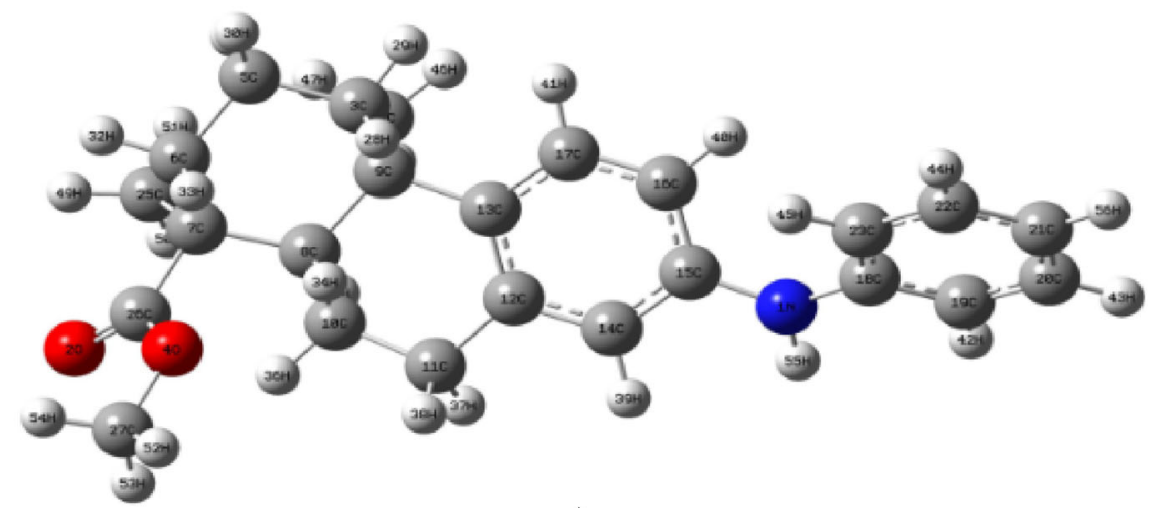

$\mathbf{A}$

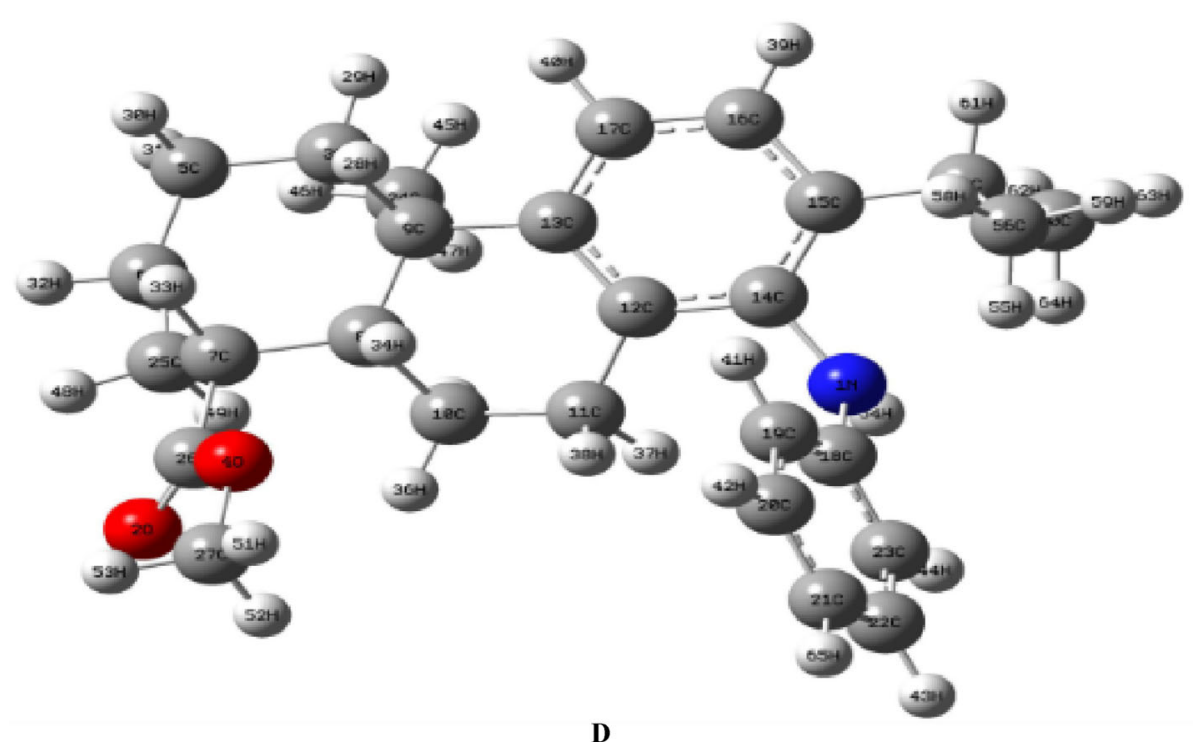

Fig. 4 Optimization geometry of compounds A and D by B3LYP/6-31G* 
Table 2 Calculated bond lengths $(\AA)$, bond angles $\left({ }^{\circ}\right)$ and torsion angles $\left({ }^{\circ}\right)$ of compounds $(\mathbf{A}-\mathbf{F})$

\begin{tabular}{|c|c|c|c|c|c|c|}
\hline \multirow{2}{*}{ Item } & \multicolumn{6}{|c|}{ Compound } \\
\hline & $\mathbf{A}$ & B & $\mathbf{C}$ & D & $\mathbf{E}$ & $\mathbf{F}$ \\
\hline \multicolumn{7}{|l|}{ Bond lengths $/ \AA$} \\
\hline $\mathrm{N}-\mathrm{C} 15$ & 1.400 & 1.397 & 1.398 & $\mathrm{~N}-\mathrm{C} 141.438$ & 1.400 & 1.401 \\
\hline $\mathrm{N}-\mathrm{C} 18$ & 1.397 & 1.404 & 1.400 & 1.393 & $\mathrm{~N}-\mathrm{C} 451.380$ & 1.392 \\
\hline $\mathrm{N}-\mathrm{H}$ & 1.011 & 1.011 & 1.010 & 1.012 & 1.015 & 1.011 \\
\hline $\mathrm{C} 15-\mathrm{C} 14$ & 1.400 & 1.401 & 1.400 & 1.400 & 1.401 & 1.401 \\
\hline \multicolumn{7}{|l|}{ Bond angles $/^{\circ}$} \\
\hline $\mathrm{C} 15-\mathrm{N}-\mathrm{C} 18$ & 129.9 & 129.4 & 129.9 & $\mathrm{C} 14-\mathrm{N}-\mathrm{C} 18124.1$ & C15-N-C45 130.9 & 130.0 \\
\hline $\mathrm{C} 15-\mathrm{N}-\mathrm{H}$ & 114.9 & 114.8 & 114.9 & C14-N-H 115.5 & 116.7 & 114.9 \\
\hline $\mathrm{C} 14-\mathrm{C} 15-\mathrm{N}$ & 123.7 & 124.0 & 123.6 & C15-C14-N 119.2 & 118.1 & 118.5 \\
\hline \multicolumn{7}{|l|}{ Torsion angles ${ }^{\circ}$} \\
\hline $\mathrm{C} 16-\mathrm{C} 15-\mathrm{N}-\mathrm{C} 18$ & -159.6 & -169.8 & -158.0 & C15-C14-N-C18 110.9 & $\mathrm{C} 16-\mathrm{C} 15-\mathrm{N}-\mathrm{C} 45 \quad 27.9$ & 27.3 \\
\hline $\mathrm{C} 14-\mathrm{C} 15-\mathrm{N}-\mathrm{C} 18$ & 22.9 & 11.6 & 24.5 & $\mathrm{C} 12-\mathrm{C} 14-\mathrm{N}-\mathrm{C} 18-70.9$ & $\mathrm{C} 14-\mathrm{C} 15-\mathrm{N}-\mathrm{C} 45-155.2$ & -156.0 \\
\hline $\mathrm{C} 15-\mathrm{N}-\mathrm{C} 18-\mathrm{C} 23$ & 25.2 & -146.9 & -158.2 & $\mathrm{C} 14-\mathrm{N}-\mathrm{C} 18-\mathrm{C} 23163.6$ & $\mathrm{C} 15-\mathrm{N}-\mathrm{C} 45-\mathrm{C} 46-170.8$ & 19.0 \\
\hline
\end{tabular}

Table 3 Selected geometric parameters of compound $\mathbf{C}$ by X-ray and DFT studies in different solvents

\begin{tabular}{|c|c|c|c|c|c|}
\hline \multirow{2}{*}{ Item } & \multirow{2}{*}{ X-ray ${ }^{[25]}$} & \multicolumn{4}{|c|}{ Calculated } \\
\hline & & Gas phase & Methanol & Water & Dichloromethane \\
\hline \multicolumn{6}{|l|}{ Bond lengths/ $/ \AA$} \\
\hline $\mathrm{N}-\mathrm{C} 15$ & 1.420 & 1.398 & 1.398 & 1.398 & 1.398 \\
\hline $\mathrm{N}-\mathrm{C} 18$ & 1.403 & 1.399 & 1.400 & 1.399 & 1.399 \\
\hline $\mathrm{N}-\mathrm{H}$ & 0.870 & 1.009 & 1.010 & 1.011 & 1.011 \\
\hline $\mathrm{C} 15-\mathrm{C} 14$ & 1.379 & 1.399 & 1.400 & 1.401 & 1.401 \\
\hline \multicolumn{6}{|l|}{ Bond angles $/{ }^{\circ}$} \\
\hline $\mathrm{C} 15-\mathrm{N}-\mathrm{C} 18$ & 123.1 & 129.8 & 129.9 & 130.0 & 129.9 \\
\hline $\mathrm{C} 15-\mathrm{N}-\mathrm{H}$ & 115.0 & 114.9 & 114.9 & 114.9 & 114.9 \\
\hline $\mathrm{C} 14-\mathrm{C} 15-\mathrm{N}$ & 112.8 & 123.5 & 123.6 & 123.8 & 123.8 \\
\hline \multicolumn{6}{|l|}{ Torsion angles $\left({ }^{\circ}\right)$} \\
\hline $\mathrm{C} 16-\mathrm{C} 15-\mathrm{N}-\mathrm{C} 18$ & 174.9 & -157.9 & -158.0 & -159.0 & -158.2 \\
\hline $\mathrm{C} 14-\mathrm{C} 15-\mathrm{N}-\mathrm{C} 18$ & -5.8 & 24.4 & 24.5 & 23.5 & 24.4 \\
\hline $\mathrm{C} 15-\mathrm{N}-\mathrm{C} 18-\mathrm{C} 23$ & 125.2 & -158.2 & -158.2 & -159.7 & -159.7 \\
\hline
\end{tabular}

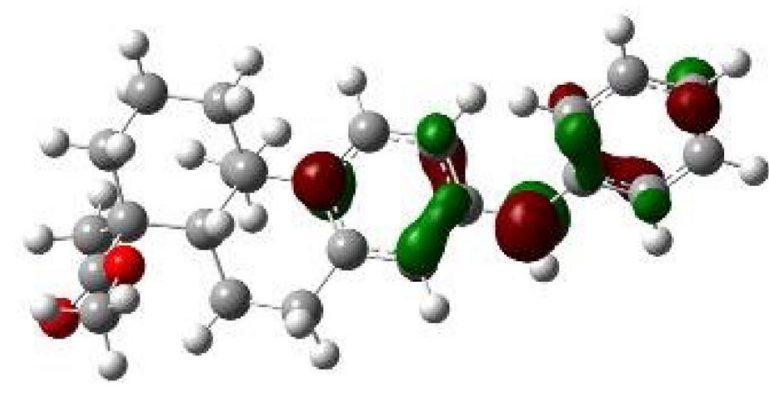

HOMO

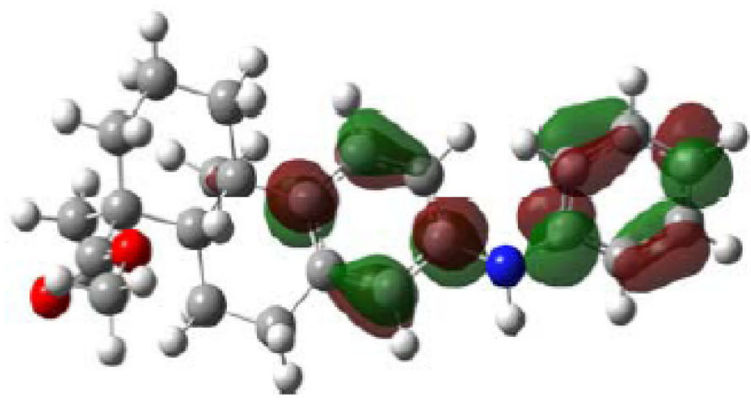

LUMO

Fig. 5 HOMO and LUMO of compound A 
rings and $\mathrm{N}$ atom except compound $\mathbf{F}$ with a bromine atom, $\pi$-electrons are mostly localized on the benzene/aryl rings in LUMOs. Calculated HOMO, LUMO energies and energy gaps ( $\left.\mathrm{E}_{\text {LUMO-HOMO }}\right)$ are shown in Table 4 . This demonstrates the polarity of solvents does not affect the HOMO-LUMO energy gap. It also can be seen from Table 4 that the electron-donating capacity of the substituent enhances the electron density on the nitrogen center. As a result, HOMO energies in methanol increase $(-5.08 \mathrm{eV}$ in $\mathbf{A},-4.99 \mathrm{eV}$ in $\mathbf{C}$ and $-4.88 \mathrm{eV}$ in $\mathbf{B})$ and energy gap values gradually decrease $(4.87 \mathrm{eV}$ in $\mathbf{A}$, $4.82 \mathrm{eV}$ in $\mathbf{C}$ and $4.71 \mathrm{eV}$ in $\mathbf{B}$ ). Unlike compounds $\mathbf{A}-\mathbf{C}$, compounds $\mathbf{E}$ and $\mathbf{F}$ have significantly smaller energy gaps, 3.63 and $4.12 \mathrm{eV}$, respectively. This is due to the fact that an extended conjugation system could lower the HOMO-LUMO energy gap and lead to an easier excitation. As a result, a red-shift of the absorption and fluorescent emission spectra would be expected. On the contrary, compound $\mathbf{D}$ has the largest energy gap, $5.07 \mathrm{eV}$, which implies that the transition from HOMO to LUMO would be harder and a resulting blueshift of the absorption and fluorescent emission spectra would be expected (Fig. 2 and Fig. 3).

Table 5 lists comparisons between the experimental and the calculated wavelength of maximum absorption. Calculated data for compounds $\mathbf{A}-\mathbf{E}$ match the experimental data. Experimental study of compound $\mathbf{F}$ found one transition peak. The theoretical peak with the largest oscillator strength at $337 \mathrm{~nm}$ is likely to correlate with the single peak in the experimental spectrum at $316 \mathrm{~nm}$. The higher-energy transition in the theoretical spectrum at
$264 \mathrm{~nm}$ is not found in the experimental spectrum, and was found to be much weaker in terms of oscillator strength $(0.24$ vs. 1.20 at $337 \mathrm{~nm})$. The broadness of the experimental transition at $316 \mathrm{~nm}$ in Fig. 2 may be obscuring this higher-energy transition observed theoretically.

\subsection{In vitro study with tumor cells}

High photostability is an important property required in the application of each photo device, including, for example, fluorescent probes. Materials exposed to light undergo degradation, which shortens their service lives by a sequence of photooxidation steps. Fluorescent spectra of sample solutions were recorded before and after UV exposure to an ultraviolet lamp light ( $9 \mathrm{~W}, 254 \mathrm{~nm}$ ) continuously for a span of $3 \mathrm{~min}$. Before measurement, the compound was dissolved in cosolvent DMSO at a concentration of $25 \mathrm{mmol} \cdot \mathrm{L}^{-1}$, and the resulting solution was diluted by deionized water to several concentrations: $1.0,2.0,5.0,10.0,12.5,15.0$, and $20.0 \mu \mathrm{mol} \cdot \mathrm{L}^{-1}$. The resulting solution was still transparent when the concentration was increased to $15 \mu \mathrm{mol} \cdot \mathrm{L}^{-1}$, which implies that the solubility of the compound in water should be above $15.0 \mu \mathrm{mol} \cdot \mathrm{L}^{-1}$. We carried out the photostability experiment using $10.0 \mu \mathrm{mol} \cdot \mathrm{L}^{-1}$ sample solution and the distance between the sample solution and the ultraviolet lamp was fixed at $20.0 \mathrm{~cm}$. Sample maps of emission spectra of compound $\mathbf{A}$ are shown in Fig. 6, and others can be found in supplementary materials (Fig. S3). Changes of fluorescent emission wavelengths and intensities are listed

Table 4 The energy levels and energy gap values of compounds (A-F) by DFT studies in different solvents

\begin{tabular}{|c|c|c|c|c|c|c|}
\hline \multirow{2}{*}{ Compound } & \multirow{2}{*}{$\mathrm{E}_{\text {Номо }} / \mathrm{eV}$ (methanol) } & \multirow{2}{*}{$\mathrm{E}_{\mathrm{LUMO}} / \mathrm{eV}$ (methanol) } & \multicolumn{4}{|c|}{$\mathrm{E}_{\text {LUмо-номо }} / \mathrm{eV}$} \\
\hline & & & Methanol & Gas & Dichlormethane & Water \\
\hline$\overline{\mathbf{A}}$ & -5.08 & -0.21 & 4.87 & 4.91 & 4.87 & 4.87 \\
\hline B & -4.88 & -0.17 & 4.71 & 4.71 & 4.71 & 4.72 \\
\hline C & -4.99 & -0.17 & 4.82 & 4.84 & 4.82 & 4.82 \\
\hline D & -5.33 & -0.22 & 5.11 & 5.07 & 5.10 & 5.11 \\
\hline $\mathbf{E}$ & -5.04 & -1.40 & 3.63 & 3.59 & 3.63 & 3.64 \\
\hline $\mathbf{F}$ & -5.06 & -0.94 & 4.12 & 3.14 & 4.14 & 4.12 \\
\hline
\end{tabular}

Table 5 Calculated UV-V is absorption peaks of compounds (A-F)

\begin{tabular}{lccccc}
\hline \multirow{2}{*}{ Compound } & \multicolumn{4}{c}{$\lambda_{\text {abs, max }} / \mathrm{nm}$} \\
\cline { 2 - 6 } & Experimental methanol & Calculated gas & Calculated methanol & Calculated dichloromethane & Calculated water \\
\hline A & 286 & 283.1 & 280.1 & 280.7 & 280.1 \\
B & 285 & 283.7 & 283.2 & 283.2 & 282.7 \\
C & 286 & 286.6 & 283.1 & 283.9 & 283.2 \\
D & 244 & 226.7 & 226.7 & 226.8 & 226.8 \\
E & $274 / 340$ & $273.3 / 400.8$ & $273.3 / 400.8$ & $274.0 / 402.5$ & $273.3 / 400.6$ \\
F & 316 & $264.1 / 337.5$ & $262.9 / 337.5$ & $264.1 / 337.5$ & $264.2 / 337.7$ \\
\hline
\end{tabular}




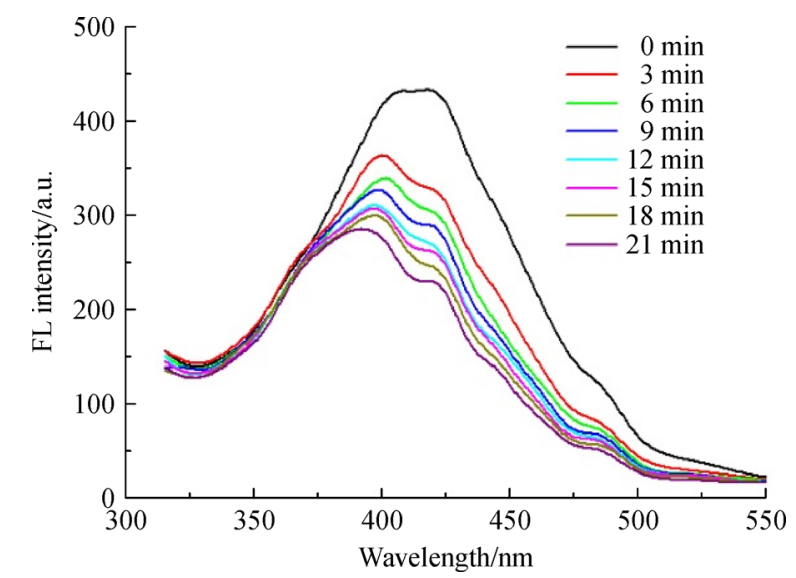

Fig. 6 Fluorescent emission spectra of compund $\mathbf{A}$ by UV irradiation

in Table 6. These fluorescent emission wavelengths demonstrate either slight blue or redshifts. Fluorescent intensities of compounds $\mathbf{A}, \mathbf{B}, \mathbf{C}, \mathbf{D}$ and $\mathbf{F}$ decreased after irradiation, while that of compound $\mathbf{E}$ increased. Given that these compounds still maintained relatively high intensity after irradiating for $12 \mathrm{~min}$, it is concluded that they have good photostability.

Cell toxicity is an important functional criterion for a fluorescent probe. Results for cell toxicity of compound $\mathbf{A}$ are shown in Fig. 7 and Fig. 8, while those for other compounds can be found in supplementary materials (Fig. S4). Figure 7 shows that the cell survival percentage decreased slowly after different concentrations of compound A were applied to A549 cells. Figure 8 shows the cell survival percentage after treatment of different cells with $1.0 \mu \mathrm{mol} \cdot \mathrm{L}^{-1}$ compound $\mathbf{A}$, including A549, SMMC7721, HeLa and SGC-7901 tumor cells, using untreated cells as a control. The results indicate that cells were viable after being treated with compounds $\mathbf{A}-\mathbf{F}$ for the same amount of time, and their cell survival percentages after being treated with compound A were 97.9\%, 96.3\%, 96.8\% and $95.9 \%$ for A549, SMMC-7721, HeLa, and SGC-7901, respectively. Cell survival percentages after treatment with compounds B-F were similar to compound A. These results imply that compounds $\mathbf{A}-\mathbf{F}$ have very low cytotoxicity at this concentration, further suggesting they

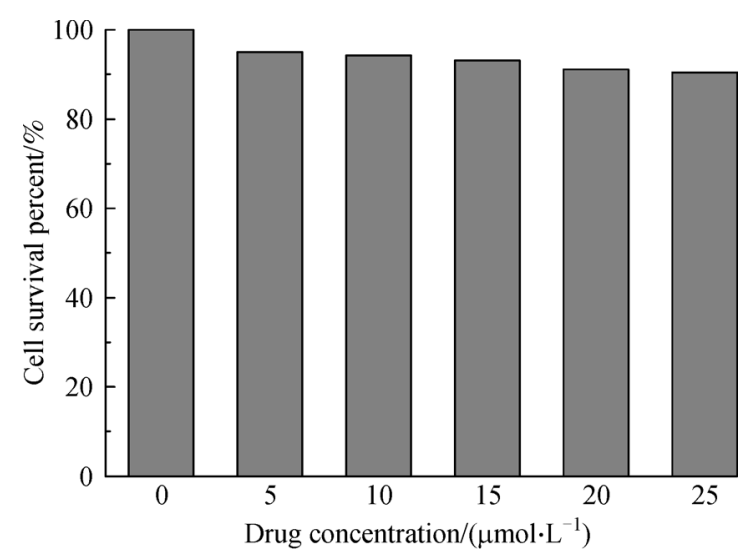

Fig. 7 Survival percent of A549 with different concentrations of A for $24 \mathrm{~h}$

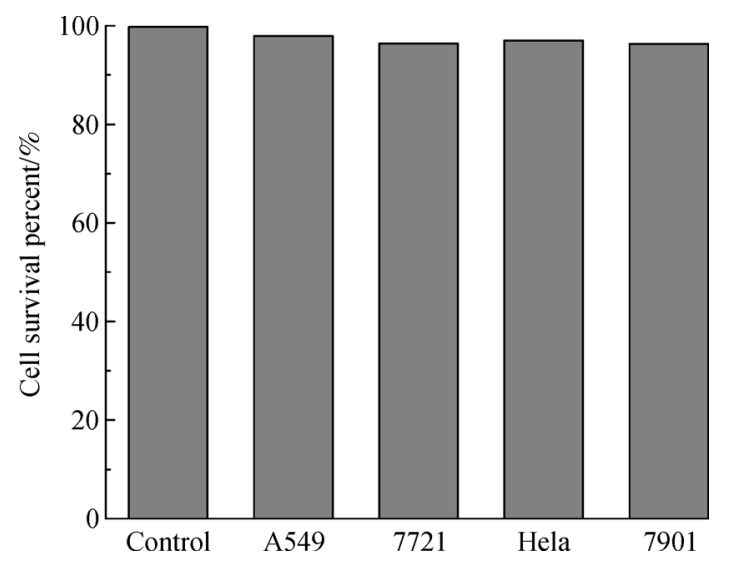

Fig. 8 Survival percent of different cells incubated with $\mathbf{A}$ $\left(1.0 \mu \mathrm{mol} \cdot \mathrm{L}^{-1}\right)$ for $24 \mathrm{~h}$

can be used as effective in vitro fluorescent probes.

Results of fluorescence imaging of compounds $\mathbf{A}$ and $\mathbf{F}$ are shown in Fig. 9, Fig. 10 and Fig. 11 [others can be found in supplementary materials (Figs. S5-S15)]. As seen in Fig. 9, compound $\mathbf{A}$ was successfully taken up by all cells, including HeLa, SMMC-7721, SGC-7901 and A549 tumor cells. Similar results were obtained for compounds $\mathbf{B}, \mathbf{C}, \mathbf{D}$ and $\mathbf{E}$. Therefore, it is likely that compounds $\mathbf{A}, \mathbf{B}$, $\mathbf{C}, \mathbf{D}$ and $\mathbf{E}$, with better detection sensitivity, which can be

Table 6 Changes of fluorescent emission wavelengths $(\Delta \lambda)$ and intensities $(\Delta \mathrm{I})$ of compounds $(\mathbf{A}-\mathbf{F})$ after UV irradiation

\begin{tabular}{lccc}
\hline Compound & $\lambda_{\text {ex }} / \mathrm{nm}$ & $\Delta \lambda\left(\lambda_{\text {em, before }}-\lambda_{\text {em, after } 12 \mathrm{~min}}\right) / \mathrm{nm}$ & $\Delta \mathrm{I}\left(\mathrm{I}_{\text {before }}-\mathrm{I}_{\text {after } 12 \mathrm{~min}}\right) / \mathrm{a} . \mathrm{u}$. \\
\hline A & 300 & $21(417-396)$ & $123(433-310)$ \\
B & 287 & $-9(368-377)$ & $199(336-137)$ \\
C & 289 & $-8(362-370)$ & $396(699-303)$ \\
D & 290 & $-30(342-372)$ & $215(453-238)$ \\
E & 260 & $1(424-423)$ & $-62(544-606)$ \\
F & 285 & $14(402-388)$ & $72(269-197)$ \\
\hline
\end{tabular}

Note: ${ }^{a}$, Intensity $\mathrm{I}_{\text {before }}$ was obtained at the emission wavelength of $\lambda_{\mathrm{em}}$, before, and Intensity $\mathrm{I}_{\mathrm{after}} 12 \mathrm{~min}$ was obtained at the emission wavelength of $\lambda_{\mathrm{em}}$, after12min. 
(a)

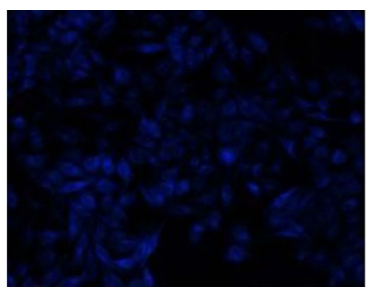

(b)

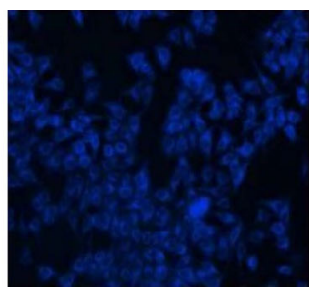

(c)

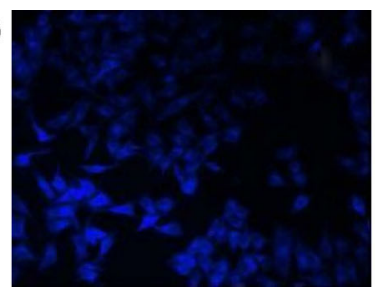

(d)

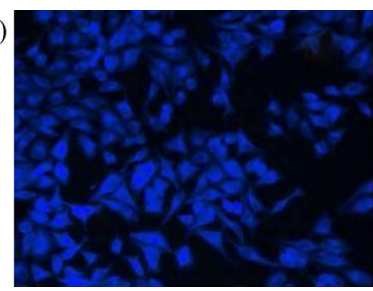

Fig. 9 Microscope fluorescence images of HeLa (a), SMMC-7721 (b), SGC-7901 (c), and A549 (d) cells treatment with compound A for $4 \mathrm{~h}$

(a)

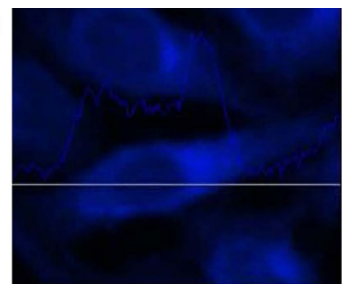

(b)

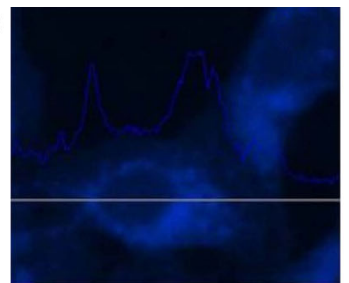

(c)

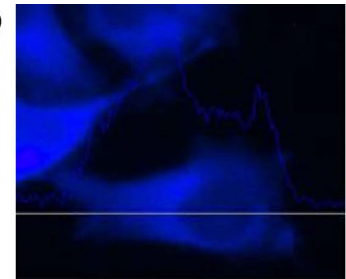

(d)

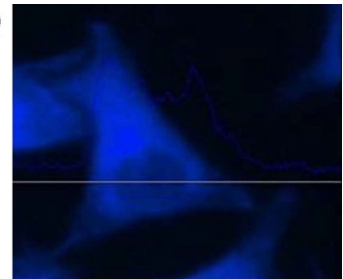

Fig. 10 Distribution of cytoplasmic and nuclear fluorescence in HeLa (a), SMMC-7721 (b), SGC-7901 (c), and A549 (d) cells treated with compound $\mathbf{A}$

(a)

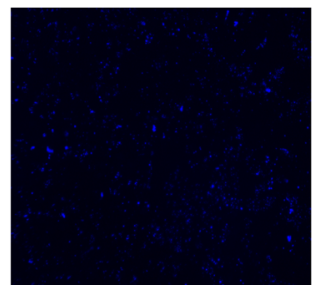

(b)

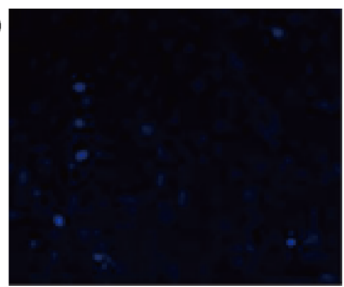

(c)

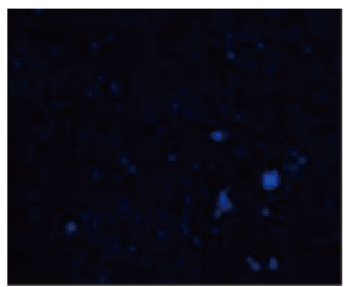

(d)

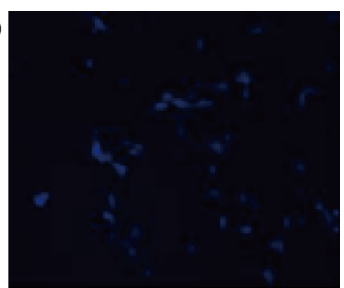

Fig. 11 Microscope fluorescence images of HeLa (a), SMMC-7721 (b), SGC-7901 (c), and A549 (d) cells treated with compound F for $4 \mathrm{~h}$

used as fluorescent probes in biological imaging.

In addition, similar distribution patterns were observed in cells treated by using compounds $\mathbf{A}-\mathbf{E}$. After trapping inside the cells, the fluorescent intensity of compounds $\mathbf{A}-$ E was not uniform. As shown in Fig. 10, the fluorescent intensity from cytoplasm was much stronger than from the nucleus. This indicates that compounds $\mathbf{A}-\mathbf{E}$ accumulated in the cytoplasm and could be used as cytoplasmic probes. However, compound F showed different fluorescence results (Fig. 11). The fluorescent signal was very weak and sparsely distributed. The low signal may imply that either compound $\mathbf{F}$ is not taken up or fluorescence quenching occurs immediately after uptake.

\section{Conclusions}

In summary, six dehydroabietic acid-based diarylamines were synthesized and characterized, with their geometries and molecular orbital surfaces optimized by DFT calculation. Molecular geometry and molecular orbital energies have an important effect on the absorption and fluorescent properties. All six compounds demonstrate high photostability and low cytotoxicity. Furthermore, in vitro tumor cell imaging experiments indicate that compounds $\mathbf{A}-\mathbf{E}$ can be effectively taken up by HeLa, SMMC-7721, SGC7901 and A549 tumor cells, with strong blue fluorescence signals detected in the cytoplasm of these cells. The above properties indicate that these compounds have the potential to be used as fluorescent probes in biological diagnostics. The explanation for the weak fluorescence of compound $\mathbf{F}$ in tumor cells requires further exploration.

Supplementary materials The online version of this article at http://dx. doi.org/10.15302/J-FASE-2017133 contains supplementary materials (Figs. S1-S15; Table S1).

Acknowledgements This work was supported by the National Natural Science Foundation of China (31670576), and Introduction of the International Advanced Forestry Science and Technology Program (20154-44).

Compliance with ethics guidelines Hong Gao, Jie Song, Shibin Shang, and Zhanqian Song declare that they have no conflicts of interest or financial 
conflicts to disclose.

All applicable institutional and national guidelines for the care and use of animals were followed.

\section{References}

1. Louie A Y. Multimodality imaging probes: design and challenges. Chemical Reviews, 2010, 110(5): 3146-3195

2. Alivisatos P. The use of nanocrystals in biological detection. Nature Biotechnology, 2004, 22(1): 47-52

3. Cho N H, Cheong T C, Min J H, Wu J H, Lee S J, Kim D, Yang J S, Kim S, Kim Y K, Seong S Y. A multifunctional core-shell nanoparticle for dendritic cell-based cancer immunotherapy. Nature Nanotechnology, 2011, 6(10): 675-682

4. Jin Y D, Gao X H. Plasmonic fluorescent quantum dots. Nature Nanotechnology, 2009, 4(9): 571-576

5. Li B, Li Q, Liu B, Yue Y F, Yu M X. The synthesis and photoluminescence characteristics of novel $\alpha, \beta$-diarylacrylonitrile derivatives containing both a biphenyl group and a triphenylamine unit. Dyes and Pigments, 2011, 88(3): 301-306

6. P Eöselt C, Schmidtke S, Fischer K, Peldschus J, Salamon H, Kloust H, Tran A, Pietsch M, Heine G, Adam U, Schumacher C, Wagener $\mathrm{S}$, Förster $\mathrm{H}$, Weller. Tailor-made quantum dot and iron oxide based contrast agents for in vitro and in vivo tumor imaging. ACS Nano, 2012, 6(4): 3346-3355

7. Almutairi A, Rossin R, Shokee M, Hagooly A, Ananth A, Capoccia B, Guillaudeu S, Abendschein D, Anderson C J, Welch M J, Fréchet J M J. Biodegradable dendritic positron-emitting nanoprobes for the noninvasive imaging of angiogenesis. Proceedings of the National Academy of Sciences of the United States of America, 2009, 106(3): 685-690

8. Kim D, Jeong Y Y, Jon S. A drug-loaded aptamer-gold nanoparticle bioconjugate for combined CT imaging and therapy of prostate cancer. ACS Nano, 2010, 4(7): 3689-3696

9. Chiu Y L, Chen S A, Chen J H, Chen K J, Chen H L, Sung H W. A dual-emission forster resonance energy transfer nanoprobe for sensing/imaging $\mathrm{pH}$ changes in the biological environment. ACS Nano, 2010, 4(12): 7467-7474

10. Park J, Dvoracek C, Lee K H, Galloway J F, Bhang H C, Pomper M G, Searson P C. CuInSe/ZnS core/shell NIR quantum dots for biomedical imaging. Small, 2011, 7(22): 3148-3152

11. Chen L N, Wang J, Li W T, Han H Y. Aqueous one-pot synthesis of bright and ultrasmallCdTe/CdS near-infrared-emitting quantum dots and their application for tumor targeting in vivo. Chemical Communications, 2012, 48(41): 4971-4973

12. Ren T R, Li Y H. Chemistry and utilization of rosin. Beijing: Chemistry Industry Press, 2006 (in Chinese)

13. Burrows H D, Fonseca S M, Gigante B, Esteves M A, Guerreiro A M. Fluorescence study of dehydroabietic acid-based bipolar arylamine-quinoxalines. Journal of Fluorescence, 2006, 16(2): 227-231

14. Burrows H D, Chattopadhyay N, Esteves M A, Fernandes M, Gigante B. Fluorescence characteristics of some dehydroabietic acid-based arylamines. Journal of Fluorescence, 2007, 17(6): 701706

15. Morgado J, Alcácer L, Esteves M A, Pires N, Gigante B. New stylbene-based arylamines with dehydroabietic acid methyl ester moieties for organic light-emitting diodes. Thin Solid Films, 2007, 515(19): 7697-7700

16. Wang Y C, Su C H, Li F Y, Liu L Z, Pan Y M, Wu X R, Wang H S. Syntheses, characterization and fluorescent properties of two series of dehydroabietic acid C-ring derivatives. Spectrochimica Acta. Part A: Molecular and Biomolecular Spectroscopy, 2010, 76(3-4): 328-335

17. Gao H, Song Z Q, Shang S B, Rao X P. Synthesis and application of dehydroabietic acid-based triarylamines. Utility Patent Application, CN 102976964A, 2012 (in Chinese)

18. Gao H, Chen S S, Rao X P, Shang S B, Song Z Q. A new dehydroabietic acid-based arylamine fluorescent probe: synthesis, structure analysis and in vitro biodiagnose function. Bioorganic \& Medicinal Chemistry Letters, 2013, 23(7): 2254-2259

19. Gao H, Song Z Q, Shang S B. Application of dehydroabietic acidbased diarylamines as fluorescent probe. Utility Patent Application, CN 103215033A, 2013 (in Chinese)

20. Frisch M J, Trucks G W, Schlegel H B, Scuseria G E, Robb M A, Cheeseman J R, Montgomery J A, Vreven T, Kudin K N, Burant J C, Millam J M, Iyengar S S, Tomasi J, Barone V, Mennucci B, Cossi M, Scalmani G, Rega N, Petersson G A, Nakatsuji H, Hada M, Ehara M, Toyota K, Fukuda R, Hasegawa J, Ishida M, Nakajima T, Honda Y, Kitao O, Nakai H, Klene M, Li X, Knox J E, Hratchian H P, Cross J B, Adamo C, Jaramillo J, Gomperts R, Stratmann R E, Yazyev O, Austin A J, Cammi R, Pomelli C, Ochterski J W, Ayala P Y, Morokuma K, Voth G A, Salvador P, Dannenberg J J, Zakrzewski V G, Dapprich S, Daniels A D, Strain M C, Farkas O, Malick D K, Rabuck A D, Raghavachari K, Foresman J B, Ortiz J V, Cui Q, Baboul A G, Clifford S, Cioslowski J, Stefanov B B, Liu G, Liashenko A, Piskorz P, Komaromi I, Martin R L, Fox D J, Keith T, Al-Laham M A, Peng C Y, Nanayakkara A, Challacombe M, Gill P M W, Johnson B, Chen W, Wong M W, Gonzalez C, Pople J A. Gaussian 03, Revision B.05, Gaussian: Pittsburgh, PA. 2003

21. Dennington R, Keith T, Millam J. GaussView, version 4, Semichem Inc., Shawnee Mission, K S, 2007

22. Lee M Y, Park S J, Park K, Kim K S, Lee H, Hahn S K. Targetspecific gene silencing of layer-by-layer assembled gold-cysteamine/siRNA/PEI/HA nanocomplex. ACS Nano, 2011, 5(8): 61386147

23. Wu F L, Shih P L, Yuan M C, Dixit A K, Shu C F, Chung Z M, Diau E W G. Novel distyrylcarbazole derivatives as hole-transporting blue emitters for electroluminescent devices. Journal of Materials Chemistry, 2005, 15(44): 4753-4760

24. Jian F F, Zhao P S, Bai Z S, Zhang L. Quantum chemical calculation studies on 4-phenyl-1-(propan-2-ylidene)thiosemicarbazide. Structural Chemistry, 2005, 16(6): 635-639

25. Gao H, Song J, Shang S B, Song Z Q. Two dehydroabietic acidbased arylamines: synthesis, crystal structure and fluorescent properties. Chinese Journal Structural Chemistry, 2013, 32(3): 396-402 